\title{
Gender, small firm ownership, and credit access: some insights from India
}

\author{
Kausik Chaudhuri • Subash Sasidharan • \\ Rajesh Seethamma Natarajan Raj
}

Accepted: 19 November 2018/Published online: 6 December 2018

(C) The Author(s) 2018

\begin{abstract}
Using a comprehensive dataset on micro, small, and medium enterprises in India, we examine whether the gender of the owner matters in firm performance and in credit access from institutional sources. The study finds significant underperformance in the size, growth, and efficiency of firms owned by women when compared to those owned by men. In line with the evidence in the existing literature, our findings also support the view that women-owned firms are disadvantaged in the market for small-business credit. These findings suggest that addressing gender discrimination in the small-business credit market could help, partly, in bridging the performance gap between male- and female-owned firms.
\end{abstract}

Keywords Gender - Small firms $\cdot$ Access to finance . India

JEL classification $\mathrm{G} 21 \cdot \mathrm{J} 16 \cdot \mathrm{L} 25 \cdot \mathrm{N} 65 \cdot \mathrm{L} 26$

K. Chaudhuri $(\bowtie)$

Leeds University Business School, Leeds University, Leeds, UK e-mail: kc@lubs.leeds.ac.uk

S. Sasidharan

Department of Humanities and Social Sciences, Indian Institute of Technology Madras, Chennai, India

e-mail: subash@iitm.ac.in

R. S. N. Raj

Department of Economics, Sikkim University, Gangtok, India e-mail: rajeshraj.natarajan@gmail.com

\section{Introduction}

It is well recognized that small firms are the engine of innovation and economic growth (Acs and Armington 2006; Baumol 2002). The OECD (2016) reports that in emerging economies, small and medium enterprises (SMEs) account for up to $45 \%$ of total employment and $33 \%$ of GDP. According to a recent study from the International Finance Corporation (IFC 2012), SMEs account for more than half of all formal jobs worldwide, and their share of aggregate employment is comparable to that of large firms. The re-evaluation of the role of small firms is related to a renewed attention to the role of entrepreneurship as it can create new economic opportunities for women and contribute to overall inclusive growth. Amorós and Bosma (2013) observes that the share of entrepreneurs remains relatively stagnant over the years and female entrepreneurs face gender biases due to various socio-economic factors. ${ }^{1}$

A related question of great policy importance on gender, entrepreneurship, and firm performance is therefore to analyze the performance of female-owned firms compared to the ones owned by males and examine the differences in their observed performance. Using firmlevel data from OECD countries, Watson (2002) and

\footnotetext{
${ }^{1}$ The total early-stage entrepreneurial activity (defined as percentage of either nascent entrepreneurs or owner-managers of new businesses in the 18-64 age group of population) in India has remained stagnant: $10.09 \%$ in 2006 and $9.88 \%$ in 2013, whereas the ratio of female to male in the same category has declined from 0.79 in 2006 to 0.49 in 2013 (source: http://gemconsortium.org/data/key-aps).
} 
Fairlie and Robb (2009) demonstrate that performance of female-owned businesses on key parameters, such as profit, size, and productivity is lower than that of maleowned businesses. But the findings differ across countries, types of firms and the control that has been used, and are also subject to criticism due to the small sample size. Sabarwal and Terell (2008), using data from Eastern Europe and Central Asia, document that femaleowned enterprises are smaller in both size of assets and employment. These findings have been echoed by Coleman (2007) in the case of 1998 US Survey of Small Business Finances. Using World Bank Enterprise Survey data, Bardasi et al. (2011) show the absence of a gender differential in value added per worker and total factor productivity while controlling for the industry in which they work. However, Bardasi et al. (2011) show that female-owned firms are less efficient in both Eastern Europe \& Central Asia and Latin America but not in sub-Saharan Africa. Using the World Bank Enterprise Survey data for the sub-Saharan African region, Aterido et al. (2011) indicate a significant gender gap in the labor coefficient and a $12 \%$ productivity gap between maleand female-owned firms.

Various factors have been put forward in the literature to explain the underperformance of female entrepreneurs: disproportionate concentration in more competitive industries or in industries with lower productivity, asymmetric access to capital and discriminatory access to finance. Coleman (2007) shows that women are concentrated in more competitive sectors such as retail and service sectors, thus getting less opportunities for growth and performance. Watson (2002) documents that poor performance of female-owned enterprises in Australia is due to lower initial start-up capital.

Although access to formal finance is often highlighted as the most pressing obstacle to the growth of small and medium enterprises (SMEs), existing literature highlights women-owned enterprises particularly suffer from difficulty in obtaining credit from formal sources (Berger and Udell 2006). ${ }^{2}$ Previous literature also highlights that women-owned firms have lower loan approval rates from formal sources indicating credit market discrimination (Muravyev et al. (2009). Using crosscountry data from the Business Environment and Enterprise Performance Survey (BEEPS), Muravyev et al.

\footnotetext{
${ }^{2}$ Numerous studies have shown the association of availability of capital in promoting the growth of small firms (Banerjee and Duflo 2010; De Mel et al. 2009).
}

(2009) observe that females face a lower probability of receiving loans and have to pay higher interest rates. As a result, women are dissuaded from entrepreneurship and running business on an efficient scale. While using the survey data for three Caribbean countries, Presbitero et al. (2014) report that women-owned businesses are more likely to be financially constrained. Their estimates indicate that firms with a predominant presence of female owners are 2.1 percentage points more likely to be credit rationed by the banking system than other firms. However, Bardasi et al. (2011) do not find evidence of gender-based discrimination in access to formal finance. The absence of gender-based discrimination is also endorsed by Aterido et al. (2013) and Storey (2004). Unlike most of the earlier studies, Hewa Wellalage and Locke (2017) report that women-owned enterprises face lower credit constraints in South Asia. Apart from credit market discrimination, women-owned businesses also face difficulties in the form of cultural barriers, concentration of business in low-productivity sectors and small size of the business, and these barriers widen the performance gap between male-run and female-run enterprises (Klapper and Parker 2011). Further, Estrin and Mickiewicz (2011) show that normative and regulatory institutions create gender differences in entrepreneurship.

Even though both male-owned and female-owned businesses face barriers in access to formal financial services, the obstacles are bigger for women-led businesses. The reasons for the observed gender gap in access to financial services may stem from both the supply and demand sides of the credit market. In a pioneering work, Becker (1957) emphasized tastebased discrimination arising from cultural and institutional factors. Various studies have extended this argument to bank-level discrimination against loan applications from women-led businesses. Further, lenders might engage in statistical discrimination (Arrow 1973) by using personal characteristics like gender and believe that women are more likely to default. The demand-side factor stresses the lower number of credit applications from women-led businesses due to the fear of refusal. Lower demand for credit by women-owned firms rise due to certain characteristics such as small size of business, "risk aversion," "perceiving themselves to be less creditworthy" (Watson and Robinson 2003), "perceiving financial barriers that do not exist," "lack of self-confidence" (Scott and Roper 2009), and sector of activity. 
Although there exists some work on OECD countries, research using data on small firms in developing countries including India is growing. For example, Coad and Tamvada (2012), using firm-level data from the third census of registered small-scale firms, showed that firms headed by females grow slower after controlling for other factors. De and Nagaraj (2014) have also used data from Indian manufacturing firms to show that firms with better liquidity turn out to be the most productive. Deshpande and Sharma (2013) highlighted the ethical and racial disparity in indicators of business performance. In a study of micro women entrepreneurs in the city of Ahmadabad (located in the state of Gujarat) in India, Kantor (2005) reports no influence of access to credit on the value added.

Our study contributes to the growing body of literature on ownership and firm performance and access to finance in the following ways. First, most of the studies were confined to the experience of developed countries and therefore, these findings cannot be easily generalized to the context of developing economies. Second, in this study, we use a unique large data set of Indian micro, small, and medium enterprises (MSMEs) to analyze the gender differences in obtaining formal finance. India presents an ideal case for two reasons: (a) the MSME sector accounts for more than $95 \%$ of the industrial units and contributes $45 \%$ of the manufacturing output and $40 \%$ of the exports (Ministry of MSME 2014). In terms of employment, the 31.1 million enterprises in the sector employ 73.2 million workers (Ministry of MSME 2011). Therefore, small enterprises play a vital role in generating employment and promoting industrialization in the Indian economy, and (b) post-independence, the policymakers in India emphasized the need to promote MSMEs and gave them favorable treatment by offering credit and tax concessions and reserving certain products only for the sector (Tendulkar and Bhavani 1997). With the onset of economic reforms, new policy initiatives led to dereservation of various items reserved for MSMEs and preference for such firms in government purchase procurements. Despite the preferential treatment of MSME sector in India, such firms are plagued by several obstacles. Among the set of constraints faced by these firms, access to finance is reported to be the most pressing obstacle (Sharma 2014). In this context, policymakers have realized the need to provide a helping hand to this sector and have undertaken a host of initiatives such as credit guarantee schemes, promotion of women entrepreneurship, and marketing assistance for accelerating the growth of this sector. Third, our dataset is rich in terms of detailed information about the presence of women in ownership and management of enterprises. Finally, a recent study noted that empirical studies on gender gap in access to finance will provide better insight into credit market functioning, if the details of different measures of female participation in the firms are taken into account (Presbitero et al. 2014). Since our dataset contains information about different measures of female participation regarding ownership and management of the firms and credit access, we are able to investigate the presence of a gender gap in access to financial instruments along with a decomposition analysis applicable to non-linear models.

The results indicate the underperformance in size and efficiency of firms owned by women when compared to those owned by men. We find that women-led enterprises are overwhelmingly represented in few (three) sectors. Further, we observe that women entrepreneurs fare worse than their male counterparts in the female dominant sectors in terms of performance. Our empirical analysis suggests that irrespective of the extent of women's involvement in the firms, women-owned firms are more likely to be denied credit than male-owned firms. The findings are thus consistent with the fact that women-owned firms face a disadvantage in the market for small-business credit, which has been traditionally attributed to discrimination. Results from the decomposition analysis show that the probability of not getting a loan varies between 2 and $4 \%$ depending on the role played by the female as owner, manager, or as both and the difference is mainly due to the endowment effect rather than the characteristics effect.

The rest of the paper is organized as follows. Details of the data source are provided in Section 2 along with the methodology. Discussion of the results obtained from the empirical exercise is reported in Section 3. Section 4 concludes the study.

\section{Data source and methodology}

\subsection{Data source}

Unlike most of the previous work relying on surveys of a small sample of firms, our study is based on Census data provided by the Ministry of Small Scale Industries, Government of India. We employ unit-level data drawn 
from the Fourth round of the Indian Micro, Small and Medium Enterprises (MSME) Survey for the year 2006-2007. ${ }^{3}$ This rich dataset contains information pertaining to 2.24 million small firms belonging to the registered and unregistered sectors. The Ministry of Small Scale Industries defines enterprises with investment of up to INR 2.5 million in plant and machinery as micro enterprises, enterprises with investment between INR 2.5 million and INR 50 million as small firms, and enterprises with investment between INR 50 million and INR 100 million as medium enterprises. The dataset contains firms belonging to manufacturing, services and repairing and maintenance sectors. In this study, we confine the analysis to the sample of firms belonging to the manufacturing sector. The database provides information related to the gender of the owner, firm's year of initial production, the sector of its operation, the gross output for three consecutive financial years, ownership type, export, loan status, quality certification, and net worth as well as information on reporting status on financial accounts by the firm.

Like any typical enterprise-level data from developing countries, our dataset also contains missing values and outlier observations that are likely to bias our estimates. Therefore, we clean the original dataset to take care of the missing observations and outliers. We follow certain procedures while undertaking the data cleaning process: First, we omit those firms which did not respond to one or more key questions. Second, we exclude those firms with seemingly unrealistic information such as missing, zero or negative output, missing labor, and capital stock values. These elimination norms reduced the number of firms in the dataset to $1,157,877$ from $1,313,210$ (about $12 \%$ of the firms in our dataset we have filtered out). We use suitable deflators (wholesale price indices) to make price corrections to the reported data on output, intermediate inputs, and value-added and fixed assets. Data related to wholesale price indices have been obtained from the report on Index Number of Wholesale Prices in India, published by the Office of the Economic Advisor, Ministry of Industry, Government of India.

Table 1 compares the mean values of our main variables of interest, by gender of the owner. It is clearly evident from the table that there exist considerable differences in firm characteristics between male-owned and female-owned firms. Compared to the male-

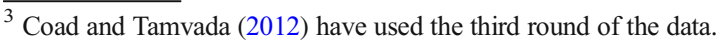

owned firms, the average production is considerably lower in female-owned firms. The average log of output for male-owned firms is 12.63 and female-owned firms is 11.25. The female-owned firms are younger and smaller in size and mostly located in urban areas as compared to male-owned firms. As regards loan availability, male business owners are more likely to obtain credit $(12 \%)$ than women (8\%). Looking at the firms' presence in the export market, male business owners are much more likely to enter export markets than women-run businesses. Thus, in terms of raw averages, female-owned firms clearly perform much worse than male-owned firms. ${ }^{4}$

\subsection{Methodology}

\subsubsection{Difference in the performance of male- and female-owned firms}

We employ a number of indicators to capture the gaps in performance between male-owned and female-owned firms. These indicators include output and employment (proxies for firm size) and efficiency as captured by labor productivity (output per worker) and total factor productivity. We obtain TFP estimates by fitting a CobbDouglas production function to firm-level data where real output is regressed on real gross fixed assets and number of workers. We control for industry and state fixed effects. ${ }^{5}$ To measure the performance gap, we regress each of the indicators of performance/ efficiency on three different dummies: dummy for female owner, dummy for female manager, and, finally, a dummy for female in dual role as owner and manager (Female).

\footnotetext{
${ }^{4}$ We follow the MSME Survey and define those entities in which one or more women entrepreneurs in proprietary concerns, or in which she/ they individually or jointly have a share capital of not less than $51 \%$ as partners/shareholders/directors of private limited company/members of cooperative society as a "woman enterprise." It takes a value of 0 for male-owned and 1 for female-owned enterprises. Our second measure identifies women-managed enterprises and takes the value one when the person managing the affairs of the unit is a woman. Further, in our third measure, we identify enterprises in which the owner as well as the person managing the affairs of the units is a woman. The variable takes the value 1 if a woman performs the dual responsibilities as owner and manager. In our dataset, $13.5 \%$ of the firms are female owned, $11 \%$ are female managed and $9.7 \%$ are female owned and managed. We have conducted a two-sample test of proportions where the null hypothesis is that the proportion is equal. In every case, we have rejected the null. ${ }^{5}$ We transform all the variables (output, capital, and labor) to their natural logarithmic values while calculating TFP.
} 
Table 1 Descriptive statistics

\begin{tabular}{|c|c|c|c|c|c|}
\hline \multirow[t]{2}{*}{ Variables } & \multicolumn{2}{|c|}{ Male owned } & \multicolumn{2}{|c|}{ Female owned } & \multirow[t]{2}{*}{$p$ value } \\
\hline & Mean & $\mathrm{SD}$ & Mean & SD & \\
\hline Log of current real output & 12.633 & 1.722 & 11.250 & 1.306 & 0.000 \\
\hline Log of employment & 1.091 & 0.920 & 0.514 & 0.701 & 0.000 \\
\hline Age & 13.156 & 9.030 & 8.772 & 6.364 & 0.000 \\
\hline Loan dummy (yes = 1) & 0.118 & - & 0.078 & - & 0.000 \\
\hline Institutional loan dummy (yes $=1$ ) & 0.099 & - & 0.070 & - & 0.000 \\
\hline Account maintenance dummy (yes $=1$ ) & 0.332 & - & 0.148 & - & 0.000 \\
\hline Location (rural/urban) & 0.545 & - & 0.422 & - & 0.000 \\
\hline Unit a part of cluster dummy & 0.080 & - & 0.038 & - & 0.000 \\
\hline Has a quality certificate dummy & 0.040 & - & 0.025 & - & 0.000 \\
\hline Export dummy & 0.034 & - & 0.012 & - & 0.000 \\
\hline Knowledge of technology dummy & 0.121 & - & 0.108 & - & 0.000 \\
\hline Log of net worth & 12.142 & 1.808 & 10.866 & 1.514 & 0.000 \\
\hline Log of real value of plant and machinery & 11.048 & 2.056 & 9.923 & 1.823 & 0.000 \\
\hline Single ownership dummy & 0.905 & - & 0.963 & - & 0.000 \\
\hline Owner of the enterprise & 0.865 & - & 0.135 & - & 0.000 \\
\hline Manager of the enterprise & 0.890 & - & 0.110 & - & 0.000 \\
\hline Both owner and manager & 0.903 & - & 0.097 & - & 0.000 \\
\hline
\end{tabular}

$p$ value is for two-sample $t$ test with unequal variances. For binary variable, we do not report the standard deviation (SD)

We further examine whether there is a preponderance of women enterprises in less productive and laborintensive sectors by computing an index that captures their representation in each sector following Bardasi et al. (2011). We define this index as follows:

$F_{R}=\frac{F_{S}}{F_{T}}$

where $F_{S}$ is the share of female entrepreneurs to total entrepreneurs in a particular sector and $F_{T}$ is the share of female entrepreneurs to total entrepreneurs in the entire MSME sector. If the value of $F_{R}$ is greater than one for a particular sector, it implies that the female entrepreneurs are overrepresented in that sector in comparison with their representation as a whole.

To examine whether the observed underperformance of women-owned enterprises is due to the overrepresentation of women in less productive sectors, we compare the relative performance of female-owned firms in female-dominated industries with those industries where they are not overrepresented. One drawback of such a comparison is the possibility of endogeneity. It is possible that the lower performance of female-owned enterprises may be explaining the lower performance of sectors where they are overcrowded. To circumvent this, we first group the industrial sectors into two categories: one category for female-dominated industrial sectors (sectors with $F_{R}>1$ ) and another for male-dominated sectors (sectors with $F_{R}<1$ ). In the next step, we employ the following specification to examine the relative performance of male- and female-owned firms:

$$
\begin{aligned}
\ln Y_{j i s}= & \beta+\text { Female }_{j i s} \\
& +{\text { } \text { Female Dominant Sector }_{j i s}} \\
& + \text {-Female }_{j i s} \\
& \times \text { Female Dominant Sector }_{j i s}+\delta X_{j i s}+\gamma_{i} \\
& +\delta_{s}+\varepsilon_{j i s}
\end{aligned}
$$

where $Y_{j i s}$ stands for performance/productivity of firm $j$ operating in industry $i$ and in state $s$. Female is the dummy for female entrepreneur which takes the value 1 for female entrepreneur and 0 for male entrepreneur. The estimated $\pi$ coefficient of Female indicates the overall performance of female firms in our dataset. Female Dominant Sector is the dummy variable for 
female-dominated sectors and its coefficient, $\alpha$, enables us to capture the differences in performance between firms in female-dominated and male-dominated sectors. The estimated $\theta$ coefficient of the interaction term $\mathrm{Fe}$ male $\times$ Female Dominant Sector yields the additional effect associated with female-owned firms operating in a female-dominated sector. $\gamma_{i}$ and $\delta_{s}$ are industry and state fixed effects respectively. Equation (1) differentiates between two implicit hypotheses of lower performance of the two categories of industries (femaledominated and male-dominated sectors) and lower performance of women entrepreneurs within these industries.

\subsubsection{Gender gap in access to finance}

To analyze the gender gap in accessing finance, we estimate a logit model where the dependent variable is loan status, i.e., whether the firm has access to external finance (loan). Female is a dummy variable taking the value of 1 for female entrepreneurship and zero otherwise. We also include a set of firm-specific control variables along with industry and state dummies. The estimated equation is:

$Y_{j i s}=\beta+\pi$ Female $_{j i s}+\delta X_{j i s}+\gamma_{i}+\delta_{s}+\varepsilon_{j i s}$

where $Y_{j i s}$ is a dummy variable which takes the value 1 if the firm $j$ operating in industry $i$ and in state $s$ obtained external finance (loan) and 0 otherwise. We use three alternate measures of female entrepreneurship as before: dummy for female owner, dummy for female manager, and a dummy for female in dual role as owner and manager. $X$ is a vector of firm-specific attributes that could influence the probability of obtaining loan. These firm-specific characteristics are also important from the lender's point of view as they reflect the creditworthiness and resources of a firm that the lender might consider while making a decision to grant a loan. To be specific, we include three alternative measures of firm performance or how well the firm is run (measured either by performance variables such as profit, or labor productivity or net worth of the firms), productivity (real value of current and lagged output), size (real value of plant and machinery), a measure of export opportunities (a dummy indicating whether or not a firm exports), the financial literacy and ability of the entrepreneur (whether or not the firm is maintaining an account and whether the firm has a quality certificate), a measure of ownership (whether the firm has a single owner or multiple owners), a measure to capture the possible effects of participating in networks (whether the firm is part of a cluster), the role of age (defined as the number of years since the firm began its operation) and its squared term and the size of the firm (measured by two proxies: employment and the amount of sales 2 years before the current period). To control for the environments in which firms operate, we include dummy for location, which takes the value 1 if the firms are operating in rural areas and 0 if they operate from urban areas. $\gamma_{i}$ is the industry fixed effects and $\delta_{s}$ denotes state fixed effects.

To disentangle the role of various factors in determining gender gap in access to finance, we also employ a decomposition technique to understand the extent to which our results are influenced by observable and unobservable components. This would allow us to explain the gap in the access to credit between the two groups of firms. The gap is decomposed into that part which is due to the group differences in predictors, i.e., the part of the gap due to the differences in the average characteristics based on the gender of the owner (the "endowment effects") and group differences in the coefficients, where the latter is sometimes called the unexplained part of the gender gap. We adopted Oaxaca (1973) decomposition technique modified for nonlinear model following Powers et al. (2011), Jann (2008), and Fairlie (2006).

\section{Results and discussion}

\subsection{Gender of the owner and performance}

In this section, we discuss the results regarding firms' performance/productivity with respect to the gender of the owner/manager. Table 2 presents the baseline results. For each performance/productivity measure, we estimate three specifications based on the extent and involvement of women in the ownership and management of firms, i.e., women as owner (column 2), women as manager (column 3), and women as owner and manager (column 4). In all the specifications, we control for age and its square as well as the size of the firms along with 2-digit SIC industry dummies and state dummies to account for unobserved heterogeneity at the industry and state levels. We include age and its square term as control variables as the differences in the age of the 
Table 2 Gender and firms' performance

\begin{tabular}{|c|c|c|c|}
\hline Variable & Women as owner & Women as manager & Women as owner and manager \\
\hline \multicolumn{4}{|l|}{ Size of the firm } \\
\hline \multicolumn{4}{|l|}{ Natural log of output } \\
\hline Female & $-0.323 * * *(0.100)$ & $-0.519 * * *(0.061)$ & $-0.567 * * *(0.049)$ \\
\hline$R$-squared & 0.511 & 0.515 & 0.515 \\
\hline \multicolumn{4}{|l|}{ Employment } \\
\hline Female & $-0.138 * *(0.070)$ & $-0.243 * * *(0.054)$ & $-0.271 * * *(0.047)$ \\
\hline$R$-squared & 0.414 & 0.417 & 0.418 \\
\hline No. of observations & $1,155,877$ & $1,155,877$ & $1,155,877$ \\
\hline \multicolumn{4}{|l|}{ Growth in output } \\
\hline Female & $-4.504(8.452)$ & $-0.777(7.217)$ & $-5.680(6.425)$ \\
\hline$R$-squared & 0.0002 & 0.0004 & 0.0002 \\
\hline Industry effects & Yes & Yes & Yes \\
\hline State effects & Yes & Yes & Yes \\
\hline No. of obs. & $1,155,877$ & $1,155,877$ & $1,155,877$ \\
\hline \multicolumn{4}{|l|}{ Efficiency } \\
\hline \multicolumn{4}{|l|}{ Labor productivity } \\
\hline Female & $-0.186^{* * *}(0.031)$ & $-0.277 * * *(0.025)$ & $-0.296 * * *(0.031)$ \\
\hline$R$-squared & 0.354 & 0.356 & 0.356 \\
\hline \multicolumn{4}{|l|}{ Total factor productivity } \\
\hline Female & $-0.246^{* *}(0.092)$ & $-0.406 * * *(0.062)$ & $-0.450 * * *(0.049)$ \\
\hline$R$-squared & 0.598 & 0.601 & 0.602 \\
\hline No. of observations & $1,155,877$ & $1,155,877$ & $1,155,877$ \\
\hline Industry effects & Yes & Yes & Yes \\
\hline State effects & Yes & Yes & Yes \\
\hline
\end{tabular}

Female stands for dummy for female as owner, female as manager, and female as both owner and manager. In all specifications, we use age and its square, firm size (using three dummy variables for micro, small and medium firms), caste of the owner (using three dummy variables for scheduled caste, scheduled tribe and other backward caste (general as the base category)), dummies controlling for type of organization, industry dummy at two-digit SIC level, and state effects. Figures in parentheses are standard errors, corrected for clustering at the industry level $* * *$ indicates significance at the $1 \%$ level, $* *$ at the $5 \%$ level, and * at the $10 \%$ level

firms owned by males and females could explain the observed gaps in the performance of male and female entrepreneurs. Women have been increasingly engaging in entrepreneurial activities recently; hence, their ventures will be much younger than the ones operated by their male counterparts. Their lower experience in managing entrepreneurial concerns might well explain their underperformance as entrepreneurs. ${ }^{6}$ Female-owned

\footnotetext{
${ }^{6}$ It needs to be stated that the relatively lower age of firms owned by females may be a result of underperformance of women entrepreneurs, as we observed in this study. If the survival rate of women owned firms are lower than that of male owned firms, it is possible that the female owned firms are on average younger than male-owned firms. Our data does not permit us to examine this hypothesis; however, it is safer to assume that younger firms are on average less experienced than older firms (Bardasi et al. 2011).
}

firms in our dataset are indeed much younger than the male-owned firms and the firms operated by male entrepreneurs are on average 4 years older than the femaleowned firms. ${ }^{7}$

Women entrepreneurship is largely skewed towards smaller-sized firms, and this gap in firm size, at least partially, could explain the existence of a gender gap in firms' performance (Marlow and McAdam 2013). ${ }^{8}$ It is argued that majority of women entrepreneurs are often in business because running a small enterprise allows them to bring in additional income with little additional effort

\footnotetext{
${ }^{7} \mathrm{~A} t$ test signifies that the difference in age is indeed significant.

${ }^{8}$ In India, almost $98 \%$ of women-owned firms are micro-enterprises, and approximately $90 \%$ of women-owned enterprises are in the informal sector (IFC 2012).
} 
and they are unlikely to expand or invest in their businesses. Previous research highlights that intention and motivation of women entrepreneurs are different from male-led businesses. Women-led businesses may be less interested in growth objectives but may be more motived by the flexibility and the personal fulfillment it offers (Klapper and Parker 2011; Morris et al. 2006). Some studies also show that women tend to display greater risk aversion, which leads them to restrict investment in their business concerns, thereby limiting the growth of their firms (Barber and Odean 2001, Dohmen et al. 2011). However, the differences in firm size may also be an outcome of the differences in survival rate of male and female-owned enterprises. If the survival rate of femaleowned firms differs from that of the male-owned firms, we would expect the female-owned enterprises to be more skewed towards smaller-sized firms. Though our dataset does not permit us to explore these two questions, it is, however, possible to analyze whether the differences in firm size explain the gender gap in firm performance. In our dataset too, about $97 \%$ of firms owned by women entrepreneurs are micro enterprises as against $85 \%$ for male-owned firms. We therefore include firm size as a control variable in our specifications. ${ }^{9}$

Our result clearly suggests that there exists a significant gap in performance between firms owned by males and those owned by females. Table 2 shows that in terms of size of the firms ${ }^{10}$ (irrespective of using output or employment), there exists a significant gender differential in performance even after controlling for age, firm size (using three dummy variables for micro, small, and medium firms), caste of the owner (using three dummy variables for scheduled caste, scheduled tribe, other backward castes (general as the base category), dummies for type of organization, and industry and state effects. The annual output of an average female-owned firm is $32 \%$ points less than the annual production of an average male-owned firm. The gap is much larger for women as manager $(51.9 \%)$ and women as owner and manager $(56.7 \%)$. Across all specifications, all measures of performance, and measures of entrepreneurship, male entrepreneurs do perform better than female entrepreneurs. Using the number of workers

\footnotetext{
${ }^{9}$ Micro enterprises are firms where the investment in plant and machinery does not exceed 25 lakh rupees; small refers to enterprises where the investment in plant and machinery is more than 25 lakh rupees but does not exceed five crore rupees; and medium are those enterprises where the investment in plant and machinery is more than five crore rupees but does not exceed ten crore rupees.

${ }^{10}$ For brevity, we do not report of the results without controls.
}

as a proxy for firm size, we find an average female-owned firm to be $13.8 \%$ points smaller than that of an average male-owned firm. Our findings are robust to our alternate measures of women entrepreneurship (women as manager and women both as manager and owner) and the gaps are found to be much larger for these alternate measures. ${ }^{11}$

Our results remain invariant when we consider efficiency/productivity instead of firm size. We observe that the TFP for the female-owned firms is significantly smaller than their male counterparts. Same holds true when we use labor productivity as an alternative - the results remain unaltered with respect to the role of female: as owner, as manager, or as both. Note all of our specifications include age and its square, size of the firms, and industry and state effects. Therefore, age and size are not the driving factors behind the findings that woman-led firms perform worse than those of their male counterparts.

Another explanation cited in the literature (Bardasi et al. 2011) related to the underperformance of female entrepreneurs is their predominance in low performing and less productive industries. We proceed as follows: we compute an index that measures the representation of women-led businesses in each sector and then compare the performance of firms in female-dominated sectors with those that are male dominated. Figure 1 demonstrates the representation of women businesses according to two-digit industry classifications. We observe that the ratio is greater than one in just three sectors, namely wearing apparel, textiles, and tobacco products.

We proceed to examine the relative performance of male- and female-owned businesses in female-dominated and male-dominated sectors by estimating Eq. (1) as stated above. Equation (1) helps us to differentiate between two implicit hypotheses of lower performance of the industries and lower performance of women entrepreneurs within these industries. Table 3 provides an insight into this explanation. We concentrate on two measures of performance: size (proxied by output) and productivity (proxied by TFP). The results reported in Table 3 confirm that the partial explanation for the underperformance of female entrepreneurs can be derived from the predominance of women enterprises in less efficient sectors. Across all estimations, the estimates of coefficients of Female and Female $\times$ Female Dominant Sector are

\footnotetext{
${ }^{11}$ Following an anonymous reviewer's suggestion and De and Nagraj (2014), we have also estimated a model where log of real value of plant and machinery has been used as size. The coefficient takes a value of0.411 (female as owner), -0.622 (female as manager), and -0.689 (female as both). All the coefficients are significant at $1 \%$ level.
} 


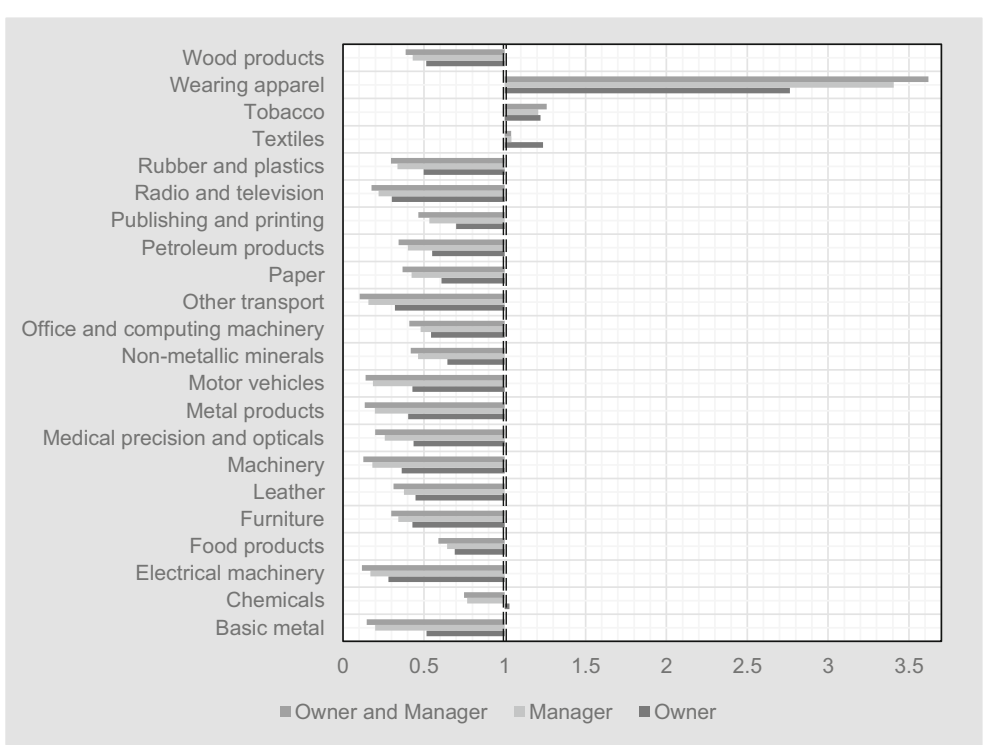

Fig. 1 Female entrepreneurs' representation by industry. Note: We define the representation of women entrepreneurs as the ratio of share of female entrepreneurs to total entrepreneurs in a particular industry to the share of female entrepreneurs to total

negative and significant. The estimated coefficient of Female dominant sector yields a negative sign across all model specifications but is significant only in two specifications (columns 3 and 4). The statistically significant results in columns 3 and 4 indicate that firms that operate in sectors that are female-dominated are relatively smaller $(-47 \%)$ and less productive $(-21 \%)$ than those firms that operate in male-dominated sectors. This perhaps lends evidence to the fact that female entrepreneurs tend to focus more on sectors that are dominated by firms which are on average smaller and less productive. The negative and significant coefficients of the interaction term Female $\times$ Female Dominant Sector suggest that the choice of sectors (female-dominated versus maledominated) does influence the gap between male and female entrepreneurs in size and performance of firms. Together, the negative and significant coefficients of Female and Female $\times$ Female Dominant Sector indicate that female-run firms operating in female dominant sectors are significantly smaller and less efficient than those that operating in male-dominated sectors. Considering the results in Tables 2 and 3 together, we observe that this skewed representation of women in certain sectors does not seem to fully explain the underperformance of firms owned by women entrepreneurs. This is clearly evident from the large and significant difference in the performance and size of male- entrepreneurs in the entire MSME sector. If the value of this index is greater than one in a particular sector, it denotes that the female entrepreneurs are overrepresented in that sector

owned and female-owned firms, even after controlling for the choice of the sector of operation. ${ }^{12}$

Our results fail to explain why female-owned firms indeed would like to be based in sectors which are poorly performing. An interesting policy question is whether women entrepreneurs are entering sectors with smaller and less efficient firms by "choice" or by "force?" If it is by choice, what are the key factors that attract them towards these sectors? If they are forced to work in these sectors, what are the key elements that exclude them from other sectors? Our dataset, however, does not permit us to undertake an analytical exercise for searching answers to these questions. However, our dataset allows us to explore whether their decision to operate in these sectors is determined by credit availability. The investigation of this issue assumes greater relevance in our present line of enquiry

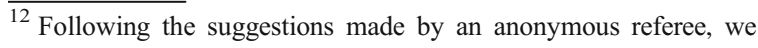
carried out a separate analysis for female-dominated sectors and male dominated sectors. When we use log of output as the dependent variable, the coefficient takes the value of -0.517 (female as owner), -0.624 (female as manager), and -0.631 (female as both) for femaledominated sectors and -0.086 (female as owner), -0.317 (female as manager), and -0.391 (female as both) for male-dominated sectors. In the case of TFP, the coefficient yields -0.544 (female as owner), 0.432 (female as manager), and -0.440 (both owner and manager) for female-dominated sectors and -0.086 (female as owner), -0.179 (female as manager), and -0.244 (female as both) for maledominated sectors. All coefficient values are significant except for the female as owner in the case of male-dominated sectors.
} 


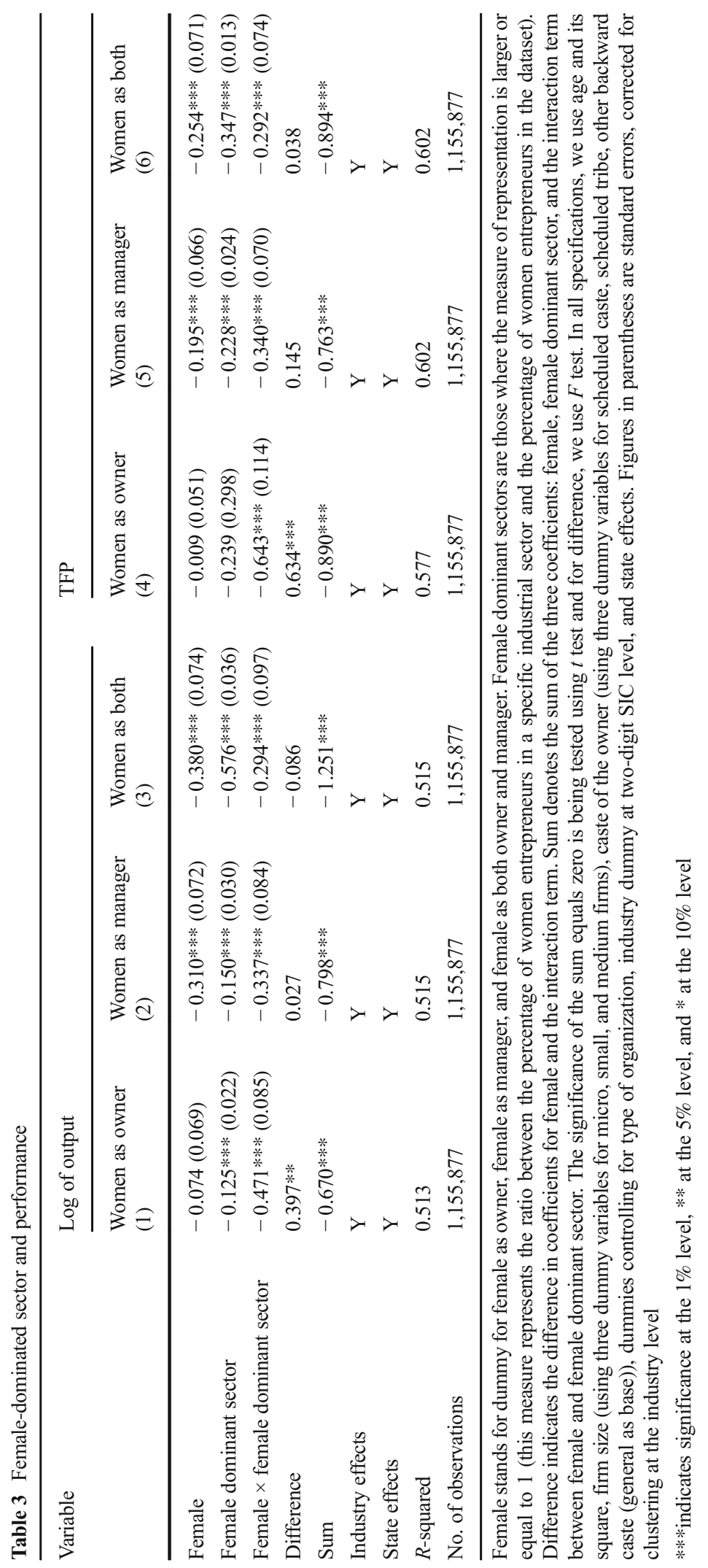


since various studies acknowledge severe barriers for women entrepreneurs in access to credit (Asiedu et al. 2013; Hansen and Rand 2014).

\subsection{Constraints to growth of women-owned firms}

To examine the gender discrimination in accessing credit, we estimate a logit equation as given in Eq. (2). The estimation results are reported in Table 4. In all the specifications, the coefficient associated with female as owner, our main variable of interest, is negative and statistically significant. According to the estimates, the odds of getting a loan for female owners is about $10.2 \%$ lower than for male owners, for all loans. The odds continue to be lower if female is manager or both owner and manager; however, the effect is not statistically significant. Considering the smaller proportion of firms that receive loans in the MSME sector, this is a fairly large number, indicating the presence of substantial gender difference in financial constraints. The impact is lower for institutional loan: the odds of getting an institutional loan for female owners is about $6.4 \%$ lower than for male owners. The gender differential is substantially higher for non-institutional loan compared to institutional loan and this is particularly interesting given that small firms depend more on noninstitutional loans rather than institutional loans. For noninstitutional loan, the coefficient associated with Female (as owner, as manager and as both) is negative and statistically significant. Turning to the location of the firm, the coefficient is not significant. Exporting firms and firms that are part of a cluster have higher odds of loan approval, which implies that lenders consider it less risky to lend to those firms that market their products abroad and that are part of a larger network. Consistent with our prior expectations, we also find that entrepreneurial ability and financial literacy do matter in eliciting a positive response from the lender. Our proxies for ability and literacy (account maintenance and possessing a quality certificate) have yielded positive coefficients, showing that lenders' satisfaction on entrepreneurial abilities increases the likelihood of loan approval. ${ }^{13}$ There is also a clear direction from our results that the probability of obtaining a loan is

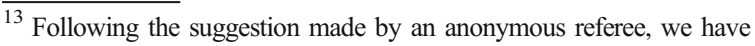
also estimated a model for institutional loan approval where we have interacted female variable with account maintenance dummy. The interaction term enters with odds ratio of 1.083 (female as owner), 1.088 (female as manager), and 1.126 (female as both) indicating that female maintaining an account experiences higher odds of loan approval. The coefficients associated with other variables remain qualitatively the same.
}

significantly higher among firms that show a better performance in terms of profitability and productivity, since the coefficients of all measures of firm performance are positive and most of them are significant across all our specifications. Age variable exerts an interesting pattern revealing a U-shaped relationship. Following Haans et al. (2016) and Lind and Mehlum (2010), we test the presence of a U-shaped relationship. In all our specifications, we notice the presence of a U-shaped relationship with respect to age and the turning point turns out to be around 39 years for all firms and those with institutional loans whereas it hovers around 29 years in case of firms with non-institutional loans. ${ }^{14}$ Furthermore, our results are also robust to alternate measures of women entrepreneurship. If we focus on the variable identifying the gender of the manager rather than female participation in ownership, the results again show evidence of gender-based discrimination in the credit market, once we condition for firms characteristics. The same result holds even when we use the variable capturing the dual role of women as owner and manager. The results reported in Table 4 remains qualitatively similar if we use output of 2 years back instead of current and lagged output. Use of better performance/productivity measures in terms of log of profit and labor productivity also did not change our results regarding the gender variable qualitatively. ${ }^{15}$

Does the reported result in Table 4 suffer from sample selection bias? Earlier studies highlight that firms often self-select not to apply for a loan (Cavalluzzo et al. 2002; Bardasi et al. 2011). Self-selection for not applying for loans may arise due to the absence of need for external finance and some of the applicants may fear a rejection. Therefore, it is essential to correct for the self-selection problem in our empirical analysis. Our empirical strategy to overcome the self-selection problem involves identifying firms as constrained and unconstrained with credit demand (Bigsten et al. 2003). We classify sample firms as "constrained" if they report a shortage of capital, while those firms receiving loans and which did not report any capital shortage were classified as "unconstrained." 16 To

\footnotetext{
${ }^{14}$ We are thankful to an anonymous referee for suggesting this analysis.

${ }^{15}$ Detailed results are available on request. We observe the partial correlation coefficient between current output, 1-year lagged output, and 2-year lagged output is 0.988 and 0.978 respectively.

${ }^{16}$ In the survey, a question is being asked: whether shortage of funds is an obstacle for satisfactory performance. We use this variable to define demand for loan as a binary variable for our biprobit model. Specifically it takes a value of 1 either for enterprises that received credit from formal or informal sources or those that reported that they were short of finance capital, otherwise 0 .
} 


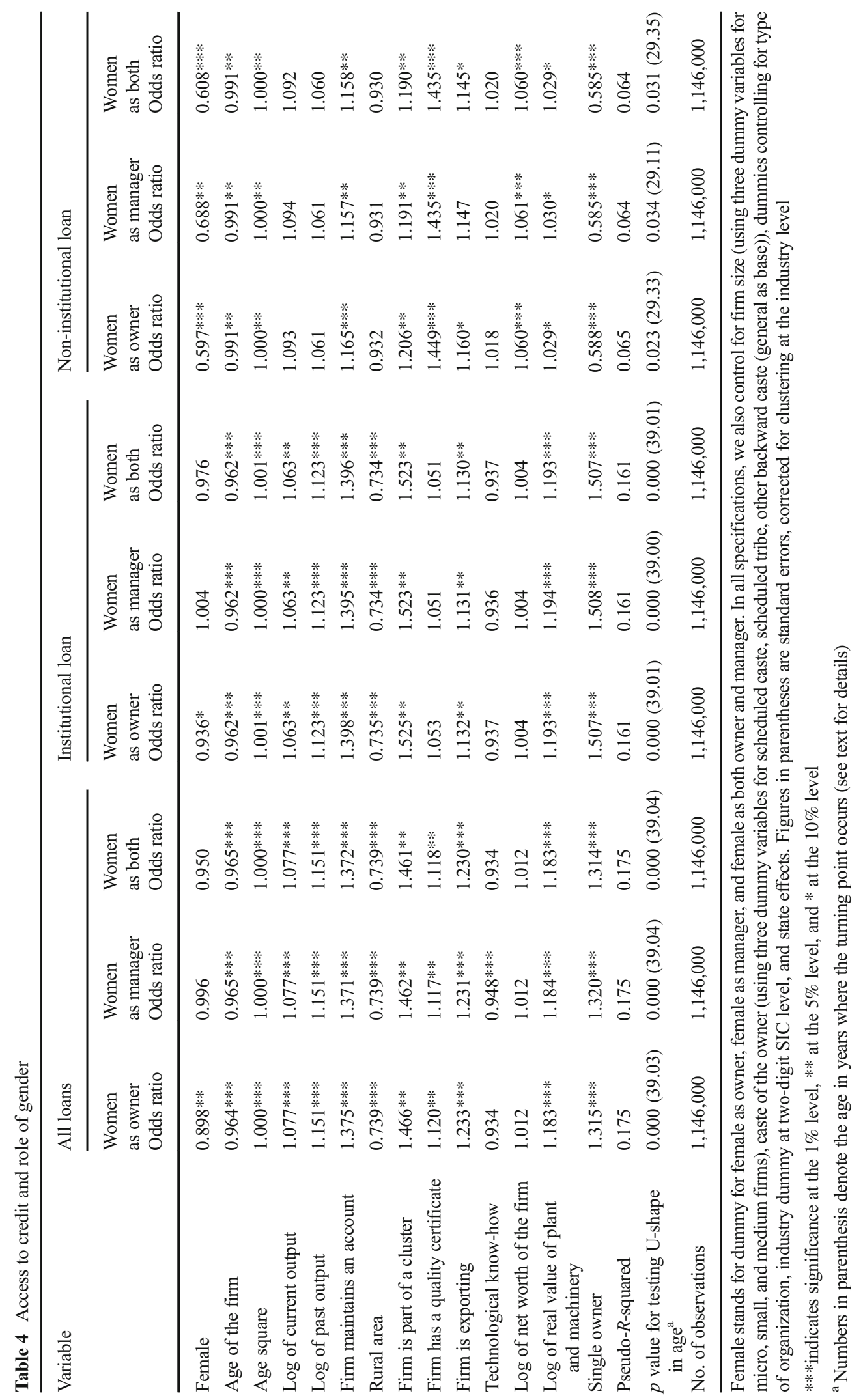


address the selection issue, we employ a bivariate probit model. We use lagged output growth as the exclusion restriction for identification purpose assuming that it influences demand for credit but not the final outcome. ${ }^{17}$ Lagged output growth is defined as the logarithmic difference of output between 2004/2005 and 2005/2006. We believe that lagged output growth would reduce the demand for credit in the current year as it would help firms to manage their operations with internal funds better. Results of our bivariate probit regression estimations after correcting for self-section are reported in Table 5. The Wald test of independent equations rejects the null hypothesis $\left(\mathrm{H}_{0}: \rho=0\right)$, validating our model specification. ${ }^{18}$

The coefficient of our variable of interest Female is negative and significant suggesting that the likelihood of receiving a bank loan is higher among male entrepreneurs as compared to female entrepreneurs. ${ }^{19}$ The estimated marginal effects show that a female owner possesses a $1 \%$ lower probability of getting a loan, which indicates they faced shortage of funds as an obstacle for satisfactory performance compared to their male counterparts. The results remain almost the same when we use female acting as both owner and manager. Other controls have maintained more or less the same sign and significance as the results for our baseline econometric specification. Our findings are thus essentially robust with regard to concerns arising from self-selection, and we conclude that

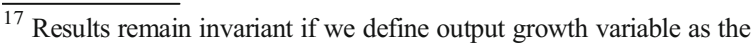
growth in output comparing the output of past 2 years with the current output. Unfortunately, the dataset does not provide any information on the reasons for not seeking loan.

${ }^{18}$ We have also tried different specifications for our bivariate probit model: (a) including both current output and lagged output in the loan equation and including real value of plant and machinery in the credit demand equation and (b) including both current output and lagged output in the loan equation, whereas including current output, lagged output, and real value of plant and machinery in the credit demand equation. In both cases, our findings remain qualitatively the same. In case (a), real value of plant and machinery enters with a positive significant coefficient in credit demand equation, whereas the sign associated with lagged output in the loan equation is negative and significant. The marginal effects show that a female owner possesses a $1 \%$ lower probability of getting a loan for case a). In case of (b), sign and significance of the coefficient associated with real value of plant and machinery remains unchanged whereas the sign associated with both current and lagged output in the loan equation is positive. In this case, the sign of lagged output in the credit demand equation is positive and significant whereas that associated with current output is negative and significant. The marginal effects show that a female owner possesses a $0.8 \%$ lower probability of getting a loan for case (b).

${ }^{19}$ We report the results for two specifications for all loans only: women as owner and women as both: owner and manager.
}

there exists clear evidence to support the existence of gender-based discrimination in the credit market. Further, we carry out the same analysis with respect to institutional and non-institutional loans. The results regarding gender discrimination in terms of obtaining a loan conditional on credit demand remains valid. ${ }^{20}$

\subsection{Decomposition of the gender gap in access to finance}

Given the existence of gender gap in access to finance, we next explain this gap using the modified version of the Blinder-Oaxaca decomposition technique. The decomposition technique is a kind of a matching where two groups are matched on a one-to-one basis. This decomposition technique helps in providing an answer to the extent to which differences in observable group characteristics can explain gender gap in access to credit. The extent to which one may attribute gender gap in credit access will depend on the choice of the reference group. The standard practice is to use the relatively more advantaged group as the reference (male-owned firms in our case) and show discrimination against less advantaged female-led firms. We decompose the gender differences in the probability of obtaining loan, using indicators of female involvement (ownership, management, ownership and management). The results of the decomposition (Table 6) show that female owners face $2 \%$ lower probability of getting a loan as compared to male entrepreneurs. The decomposition output, the gap in probability of getting a loan across the gender, is divided into three parts. The first part (endowment) reflects the mean increase in female's success probability if they had the same characteristics as male, whereas the second part (coefficients) shows the change in female's success probability when applying the men's coefficients to the female's characteristics. The third part is the interaction term that measures the simultaneous effect of differences in endowments and coefficients. For female manager (fourth column, Table 6), the probability of getting a loan is $3.3 \%$ lower than males and it is mainly due to the endowment effects. We observe that the probability of not getting a loan increases to $4 \%$ when female acts as both owner and manager. Although not reported, we also perform the same analysis for institutional loans. ${ }^{21}$ For female, the probability of

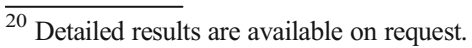

${ }^{21}$ Results are available on request.
} 
Table 5 Bivariate probit model and gender discrimination

\begin{tabular}{|c|c|c|}
\hline Variables & $\begin{array}{l}\text { Women as owner } \\
\text { Coefficients (marginal effects) }\end{array}$ & $\begin{array}{l}\text { Women as owner and manager } \\
\text { Coefficients (marginal effects) }\end{array}$ \\
\hline \multicolumn{3}{|l|}{ Dependent variable: obtained loan } \\
\hline Female & $-0.069(-0.010)^{* *}$ & $-0.058(-0.008)^{*}$ \\
\hline Age of the firm & $-0.020(-0.003)^{* * *}$ & $-0.019(-0.003)^{* * *}$ \\
\hline Age square & $0.0002 * * *$ & $0.0002 * * *$ \\
\hline Log of current output & $0.127(0.018)^{* * *}$ & $0.127(0.018)^{* * *}$ \\
\hline Firm maintains an account & $0.185(0.028)^{* * *}$ & $0.184(0.028)^{* * *}$ \\
\hline Rural area & $-0.148(-0.022)^{* * *}$ & $-0.149(-0.021)^{* * *}$ \\
\hline Firm is part of a cluster & $0.183(0.030)^{*}$ & $0.181(0.029)^{*}$ \\
\hline Firm has a quality certificate & $0.080(0.012)^{* *}$ & $0.079(0.012)^{* *}$ \\
\hline Firm is exporting & $0.094(0.014)^{* * *}$ & $0.093(0.014)^{* * *}$ \\
\hline Technological know-how & $-0.014(-0.002)$ & $-0.014(-0.002)$ \\
\hline Log of net worth of the firm & $0.050(0.007)^{* * *}$ & $0.051(0.007) * * *$ \\
\hline Single owner & $0.167(0.022)^{* * *}$ & $0.166(0.022)^{* * *}$ \\
\hline \multicolumn{3}{|c|}{ Dependent variable: demand for loan } \\
\hline Female & $-0.064 * *$ & $-0.053 *$ \\
\hline Age of the firm & $-0.019 * * *$ & $-0.019 * * *$ \\
\hline Age square & $0.0002 * * *$ & $0.0002 * * *$ \\
\hline Log of current output & $0.123 * * *$ & $0.122 * * *$ \\
\hline Firm maintains an account & $0.184 * * *$ & $0.184 * * *$ \\
\hline Rural area & $-0.146^{* * *}$ & $-0.146 * * *$ \\
\hline Firm is part of a cluster & $0.200 *$ & $0.198 *$ \\
\hline Firm has a quality certificate & $0.087 * *$ & $0.086^{* *}$ \\
\hline Firm is exporting & $0.095 * * *$ & $0.094 * * *$ \\
\hline Technological know-how & -0.015 & $-0.015 * * *$ \\
\hline Log of net worth of the firm & $0.047 * * *$ & $0.047 * * *$ \\
\hline Single owner & $0.159 * * *$ & $0.158 * * *$ \\
\hline Output growth $_{t-1}$ & $-0.017 * * *$ & $-0.017 * * *$ \\
\hline$p$ value for $\left(\mathrm{H}_{0}: \rho=0\right)$ & 0.000 & 0.000 \\
\hline No. of observations & $1,149,247$ & $1,149,247$ \\
\hline
\end{tabular}

Female stands for dummy for female as owner and female as both owner and manager. In all specifications, firm size (using three dummy variables for micro, small, and medium firms), caste of the owner (using three dummy variables for scheduled caste, scheduled tribe, other backward caste (general as base)), dummies controlling for type of organization, industry dummy at two-digit SIC level, and state effects. Marginal effects reported in parenthesis are for probability of loan approval (taking the value of one) conditional on credit demand (taking the value of one). Figures in parentheses are standard errors, corrected for clustering at the industry level. Given square of age is a monotonic transformation of age, we report the marginal effect for only age

$* * *$ indicates significance at the $1 \%$ level, $* *$ at the $5 \%$ level, and $*$ at the $10 \%$ level

getting an institutional loan is $1 \%, 2.9 \%$, and $2.4 \%$ lower than males for female owner, female owner and manager, and female manager respectively, and it is again mainly due to the endowment effects.

\section{Conclusion}

The study presents new evidence on whether the gender of the owner influences firm performance and credit access from institutional sources. We employ unit-level 
Table 6 Non-linear decomposition of gender discrimination in access to all loans

\begin{tabular}{llll}
\hline & Women as owner & Women as owner and manager & Women as manager \\
\hline Differential & Coefficient & Coefficient & Coefficient \\
$\quad$ Prediction (male) & $0.117(0.003)^{* * * *}$ & $0.118(0.0003)^{* * *}$ & $0.118(0.0003)^{* * *}$ \\
Prediction (female) & $0.099(0.001)^{* * *}$ & $0.078(0.001)^{* * *}$ & $0.085(0.001)^{* * *}$ \\
Difference & $0.018(0.001)^{* * *}$ & $0.040(0.001)^{* * *}$ & $0.033(0.001)^{* * *}$ \\
Decomposition & & & $0.050(0.001)^{* * *}$ \\
Endowments & $0.020(0.001)^{* * *}$ & $0.055(0.002)^{* * *}$ & $0.005(0.001)^{* * *}$ \\
Coefficients & $0.013(0.001)^{* * * *}$ & $0.008(0.001)^{* * *}$ & $-0.022(0.001)^{* * *}$ \\
Interaction & $-0.015(0.001)^{* * *}$ & $-0.023(0.001)^{* * *}$ & $1,149,247$ \\
No. of observations & $1,149,247$ & $1,149,247$ & \\
\hline
\end{tabular}

In all specifications, we include age and its square, log of output, dummy for firm maintaining an account, rural area dummy, dummy for firm be part of a cluster, dummy for firm having a quality certificate, dummy for whether firm is exporting, dummy technological know-how, log of net worth of the firm, dummy for single owner, firm size (using three dummy variables for micro, small and medium firms), caste of the owner (using three dummy variables for scheduled caste, scheduled tribe, other backward caste (general as base)), dummies controlling for type of organization, industry dummy at two-digit SIC level, and state effects. Figures in parentheses are standard errors, corrected for clustering at the industry level

$* * *$ indicates significance at the $1 \%$ level, $* *$ at the $5 \%$ level, and * at the $10 \%$ level

dataset for registered and unregistered enterprises, drawn from the Fourth Survey round on the Indian Micro, Small and Medium Enterprises carried out for the period 2006-2007. Our findings are broadly in line with the previous studies on women entrepreneurship in developed and emerging economies. In the first part of the empirical analysis, we attempt to measure the gender gaps in performance in terms of output, employment, labor productivity, and total factor productivity. We observe significant differences in the performance gap between male- and female-owned enterprises even after controlling for size, age, social background, and industry and state differences. We also observe that there is a preponderance of women enterprises in a few sectors which are typically considered as feminine occupations (see Marlow and Patton 2007; Ghani et al. 2017). Taking this into account, we test whether the performance differential arises due to the predominance of women enterprises in certain sectors. We find that female-run firms operating in female dominant sectors are significantly smaller and less efficient than those that operate in male-dominated sectors, which suggests that a partial explanation of the underperformance of female entrepreneurs can be derived from this skewed representation. However, the large and significant differences in the performance and size of male-owned and femaleowned firms, even after controlling for the choice of the sector of operation, shows that the preponderance of women entrepreneurs in certain sectors alone does not fully explain the underperformance of firms owned by women entrepreneurs.

As several studies have highlighted the severe impediments that women-owned firms face in obtaining credit, we investigate whether there are significant gender discrimination against women entrepreneurs for formal credit in the small-firm credit market. Unlike the existing studies, our dataset provides an opportunity to analyze the gender gap in credit access using various measures of women involvement in the ownership and management of the enterprises. Our econometric exercise points out unambiguously that irrespective of the extent of women's involvement in the firms, women-led businesses are less likely to obtain formal finance. We find that male-owned firms have about a $10-12 \%$ higher odds probability of obtaining a loan as compared to women-owned firms. Various robustness tests that we undertook support the existence of gender-based discrimination in the credit market. The findings are thus consistent with the fact that womenowned firms are disadvantaged in the market for small-business credit, which has been traditionally attributed to discrimination.

Our empirical analysis indicates that addressing the gender discrimination in the small-business credit market could help, partly, in bridging the performance gap between male- and female-owned firms. Therefore, policymakers need to focus their efforts to offer more credit and support for female-owned enterprises. 
Another possible policy option is to develop credit registries which can help the women entrepreneurs in overcoming the information asymmetry in the credit market. The evidence presented in the study opens up interesting avenues for future research on women entrepreneurship and a possible extension to other emerging economies.

Acknowledgments We thank Julie Ann Elston, the Associate Editor, and two anonymous reviewers for their detailed comments which helped us to improve the paper substantially. Editorial help from David Clark, Joe Varghese Yeldho, Radeef Chundakkadan, and Prabin Chhetri are highly appreciated.

Open Access This article is distributed under the terms of the Creative Commons Attribution 4.0 International License (http:// creativecommons.org/licenses/by/4.0/), which permits unrestricted use, distribution, and reproduction in any medium, provided you give appropriate credit to the original author(s) and the source, provide a link to the Creative Commons license, and indicate if changes were made.

Publisher's Note Springer Nature remains neutral with regard to jurisdictional claims in published maps and institutional affiliations.

\section{References}

Acs, Z., \& Armington, C. (2006). Entrepreneurship, geography, and American economic growth. Cambridge: Cambridge University Press.

Amorós, J. E., \& Bosma, N. (2013). Global entrepreneurship monitor: 2013 global report. Babson Park: Babson College.

Arrow, K. J. (1973). The theory of discrimination. In O. Ashenfelter \& A. Rees (Eds.), Discrimination in labor markets (pp. 3-33). Princeton: Princeton University Press.

Asiedu, E., Kalonda-Kanyama, I., Ndikumana, L., \& Nti-Addae, A. (2013). Access to credit by firms in sub-Saharan Africa: how relevant is gender? American Economic Review, 103(3), 293-297.

Aterido, R., Hallward-Driemeier, M., \& Pagés, C. (2011). Big constraints to small firms' growth? business environment and employment growth across firms. Economic Development and Cultural Change, 59(3), 609-647.

Aterido, R., Beck, T., \& Iacovone, L. (2013). Access to finance in sub-Saharan Africa: is there a gender gap? World Development, 47(7), 102-120. https://doi.org/10.1016/j. worlddev.2013.02.013.

Banerjee, A. V., \& Duflo, E. (2010). Giving credit where it is due. Journal of Economic Perspectives, 24(3), 6180. https://doi.org/10.1257/jep.24.3.61.

Barber, B. M., \& Odean, T. (2001). Boys will be boys: gender, overconfidence, and common stock investment. Quarterly Journal of Economics, 116(1), 261-292. https://doi.org/10.1162/003355301556400.
Bardasi, E., Sabarwal, S., \& Terrell, K. (2011). How do female entrepreneurs perform? Evidence from three developing regions. Small Business Economics, 37(4), 417-441. https://doi.org/10.1007/s11187-011-9374-z.

Baumol, W. (2002). The free-market innovation machine: analyzing the growth miracle of capitalism. Princeton: Princeton University Press.

Becker, G. (1957). The economics of discrimination. Chicago: Chicago University Press.

Berger, A. N., \& Udell, G. F. (2006). A more complete conceptual framework for SME finance. Journal of Banking and Finance, 30(11), 2945-2966.

Bigsten, A., Collier, P., Dercon, S., Fafchamps, M., Gauthier, B., Gunning, J. W., Oduro, A., Oostendoop, R., Patillo, C., Söderbom, M., Teal, F., \& Zeufack, A. (2003). Credit constraints in manufacturing enterprises in Africa. Journal of African Economies, 12(1), 104-125. https://doi.org/10.1093 /jae/12.1.104.

Cavalluzzo, K., Cavalluzzo, L., \& Wolken, J. (2002). Competition, small business financing, and discrimination: evidence from a new survey. Journal of Business, 75(4), 641-679.

Coad, A., \& Tamvada, P. (2012). Firm growth and barriers to growth among small firms in India. Small Business Economics., 39(2), 383-400. https://doi.org/10.1007 /s11187-011-9318-7.

Coleman, S. (2007). The role of human and financial capital in the profitability and growth of women-owned small firms. Journal of Small Business Management, 45(3), 303-319. https://doi.org/10.1111/j.1540-627X.2007.00214.x.

De, P. K., \& Nagaraj, P. (2014). Productivity and firm size in India. Small Business Economics, 42(4), 891-907. https://doi. org/10.1007/s11187-013-9504-x.

Deshpande, A., \& Sharma, S. (2013). Entrepreneurship or survival? Caste and gender of small business in India. Economic and Political Weekly, 63(28), 38-49.

Dohmen, T., Falk, A., Huffman, D., Sunde, U., Schupp, J., \& Wagner, G. G. (2011). Individual risk attitudes: measurement, determinants, and behavioral consequences. Journal of the European Economic Association, 9(3), 522-550. https://doi.org/10.1111/j.1542-4774.2011.01015.x.

Estrin, S., \& Mickiewicz, T. (2011). Institutions and female entrepreneurship. Small Business Economics, 37(4), 397-415. https://doi.org/10.1007/s11187-011-9373-0.

Fairlie, R. (2006). Entrepreneurship among disadvantaged groups: women, minorities and the less educated. In S. C. Parker, J. Zoltan, \& D. R. Audretsch (Eds.), International handbook series on entrepreneurship (Vol. 2, pp. 437-475). New York: Springer.

Fairlie, R., \& Robb, A. (2009). Gender differences in business performance: evidence from the characteristics of business owners survey. Small Business Economics, 33(4), 375-395. https://doi.org/10.1007/s11187-009-9207-5.

Ghani E., Goswai, A.G. Kerr, S., \& Kerr, W. (2017). Will market competition trump gender discrimination in India?. World Bank Policy Research Working Paper 7814. The World Bank.

Haans, R. F. J., Pieters, C., \& He, Z. L. (2016). Thinking about U: theorizing and testing $\mathrm{U}$ - and inverted U-shaped relationships in strategy research. Strategic Management Journal, 37(7), 1177-1195. https://doi.org/10.1002/smj.2399. 
Hansen, H., \& Rand, J. (2014). The myth of female credit discrimination in African manufacturing. Journal of Development Studies., 50(1), 81-96. https://doi. org/10.1080/00220388.2013.849337.

Hewa Wellalage, N., \& Locke, S. (2017). Access to credit by SMEs in South Asia: do women entrepreneurs face discrimination. Research in International Business and Finance, 41, 336-346. https://doi.org/10.1016/j.ribaf.2017.04.053.

International Finance Corporation. (2012). Micro, small and medium enterprise finance in India. New Delhi: World Bank Group.

Jann, B. (2008). FAIRLIE: Stata module to generate nonlinear decomposition of binary outcome differentials. Statistical Software Components. Boston: Boston College Department of Economics.

Kantor, P. (2005). Determinants of women's microenterprise success in Ahmedabad, India: empowerment and economics. Feminist Economics., 11(3), 63-83. https://doi.org/10.1080 /13545700500301163.

Klapper, L. F., \& Parker, S. C. (2011). Gender and the business environment for new firm creation. World Bank Research Observer, 26(2), 237-257. https://doi.org/10.1093 /wbro/lkp032.

Lind, J. T., \& Mehlum, H. (2010). With or without U? The appropriate test for a U-shaped relationship. Oxford Bulletin of Economics and Statistics, 72(1), 109-118. https://doi. org/10.1111/j.1468-0084.2009.00569.x.

Marlow, S., \& McAdam, M. (2013). Gender and entrepreneurship: advancing debate and challenging myths; exploring the mystery of the under-performing female entrepreneur. International Journal of Entrepreneurial Behaviour and Research, 19(1), 114-124. https://doi.org/10.1108 /13552551311299288.

Marlow, S., \& Patton, D. (2007). All credit to men? Entrepreneurship, finance and gender. Entrepreneurship Theory Practice, 29(6), 717-735. https://doi.org/10.1111 j.1540-6520.2005.00105.x.

De Mel, S., McKenzie, D., \& Woodruff, C. (2009). Are women more credit constrained?: experimental evidence on gender and microenterprise returns. American Economic Journal: Applied Economics, 1(3), 1-32. https://doi.org/10.1257 /app.1.3.1.

Ministry of MSME (2011). Final report of fourth all india census of MSME 2006-07: registered sector. http://fisme.org. in/document/FinalReport010711.pdf.

Ministry of MSME. (2014). Annual report 2013-14. New Delhi: Government of India.
Morris, M. H., Miyasaki, N. N., Watters, C. E., \& Coombes, S. M. (2006). The dilemma of growth: understanding venture size choices of women entrepreneurs. Journal of Small Business Management, 44(2), 221-244. https://doi.org/10.1111 j.1540-627X.2006.00165.x.

Muravyev, A., Talavera, O., \& Schäfer, D. (2009). Entrepreneurs' gender and financial constraints: evidence from international data. Journal of Comparative Economics, 37(2), 270-286. https://doi.org/10.1016/j.jce.2008.12.001.

Oaxaca, R. (1973). Male-female wage differentials in urban labor markets. International Economic Review, 14(3), 693-709.

OECD. (2016). Entrepreneurship at a glance 2016. Paris: OECD Publishing.

Powers, D. A., Yoshioka, H., \& Yun, M.-S. (2011). mvdemp: multivariate decomposition for nonlinear response models. The Stata Journal, 11(4), 556-576.

Presbitero, A. F., Rabellotti, R., \& Piras, C. (2014). Barking up the wrong tree? Measuring gender gaps in firm's access to finance. Journal of Development Studies, 50(10), 1430-1444. https://doi.org/10.1080/00220388.2014.940914.

Sabarwal, S., \& Terrell, K. (2008). Does gender matter for firm performance? evidence from Eastern Europe and Central Asia. World Bank Policy Research Working Paper No.4705. Washington DC: World Bank.

Scott, J., \& Roper, S. (2009). Perceived financial barriers and the start-up decision: an econometric analysis of gender differences using GEM data. International Small Business Journal, 27(2), 149-171. https://doi. org/10.1177/0266242608100488.

Sharma, S. (2014). Benefits of a registration policy for microenterprise performance in India. Small Business Economics 42(1), 153-164. https://doi.org/10.1007/s11187-013-9475-y.

Storey, D. J. (2004). Racial and gender discrimination in the micro firms credit market? Evidence from Trinidad and Tobago. Small Business Economics, 23(5), 401422. https://doi.org/10.1007/s11187-004-7259-0.

Tendulkar, S., \& Bhavani, T. A. (1997). Policy on modern small scale industries: a case of government failure. Indian Economic Review, 32(1), 39-64.

Watson, J. (2002). Comparing the performance of male- and female-controlled businesses: relating outputs to inputs. Entrepreneurship Theory and Practice, 26(3), 91-100. https://doi.org/10.1108/14626000310473265.

Watson, J., \& Robinson, S. (2003). Adjusting for risk in comparing the performance of male and female controlled SMEs. Journal of Business Venturing, 18(6), 773-788. https://doi.org/10.1016/S0883-9026(02)00128-3. 